\title{
KOMPETENCJE PRACOWNIKÓW SOCJALNYCH W ASPEKCIE STRESU I RADZENIA SOBIE ZE STRESEM
}

\begin{abstract}
Competences of social workers in the aspect of stress and coping with stress

One of the basic skills that a modern social worker should be equipped with is stress management. This ability allows you to constructively carry out professional tasks and can become a buffer to counteract stress and burnout. Are the appropriate competences an individual's resource in counteracting stress? Do educated skills during education help a social worker deal with stress? The article is a presentation of the search for relationships and relationships between competences and stress. Particular attention was paid to coping with stress.
\end{abstract}

Key words: stress, coping with stress, competences, self-esteem, social worker

\section{Wprowadzenie}

Praca socjalna jako profesja wspierająca zmianę społeczną, rozwiązywanie problemów powstających w relacjach międzyludzkich oraz wzmocnienie (empowerment) i wyzwalanie ludzi dla poprawy ich dobrostanu (Beckett 2010: 15) wyznacza role zawodowe pracowników socjalnych, a tym samym szerokie kompetencje. Działania pracownika socjalnego opierają się na trzech podstawowych filarach, to jest wiedzy, umiejętnościach i postawach. Głównym celem pracy z klientem pomocy społecznej jest wsparcie jednostki z różnych względów niepotrafiącej samodzielnie poradzić sobie w swoim życiu, a patogenna sytuacja, w której się znajduje, wymaga interwencji osoby mogącej pomóc jej podjąć walkę o przezwyciężenie dotychczasowych problemów. $Z$ uwagi na znaczenie i rangę zawodu pracownik socjalny powinien posiadać odpowiednie kwalifikacje oraz kompetencje, aby w prawidłowy sposób wykonywać zadania zawodowe, rozwijać swój warsztat pracy, osobowość oraz umiejętności radzenia sobie w różnych sytuacjach. Ważne miejsce w pracy w zawodach społecznych zajmują kompetencje, czyli „wszystkie cechy pracowników (wiedza, umiejętności, doświadczenia, zdolności, ambicje, wyznawane wartości, style działania), których posiadanie, rozwijanie i wykorzystywanie przez pracowników umożliwia realizację strategii organizacji, w której są zatrudnieni” 
(Szczęsna, Rostkowski 2004: 41). Szczególnie istotne wydaje się ich znaczenie w aspekcie odczuwalnego stresu zawodowego oraz radzenia sobie z nim.

Od kilku lat szerzej mówi się o trudnościach zawodu pracownika socjalnego i zagrożeniach wynikających z pracy z klientem. W świetle uzyskanych danych empirycznych zauważa się, że zawód pracownika socjalnego jest zawodem stawiającym bardzo wysokie wymagania wobec osób podejmujących aktywność zawodową w instytucjach pomocy społecznej. Dzieje się tak z uwagi na różnorodność ról zawodowych, obciążenia psychiczne i fizyczne oraz czynniki organizacyjne (Stanek 2016: 208-210). Wyniki badań własnych skłoniły do dalszych poszukiwań empirycznych. Skoro pracownicy socjalni są w dużej mierze narażeni na stres i wypaleni zawodowo, to co jest buforem przeciwdziałającym temu zjawisku oraz pozwala w konstruktywny sposób rodzić sobie ze stresem? Czy odpowiednie kompetencje stanowią zasób jednostki w przeciwdziałaniu stresowi? Czy rozwinięte umiejętności w toku kształcenia pomagają pracownikowi socjalnemu radzić sobie ze stresem?

\section{Podstawy teoretyczne badań}

Kompetencje zawodowe, które powinien posiadać pracownik socjalny, wynikają z pełnionych przez niego ról zawodowych, a te z zadań zawodowych, które przed nim stoją w połączeniu z umiejętnościami, aby prawidłowo je wykonywać. Wśród zadań pracownika socjalnego wyróżnia się między innymi dokonywanie analizy i oceny zjawisk rodzących zapotrzebowanie na świadczenia pomocy społecznej oraz udzielanie osobom informacji, wskazówek i pomocy w zakresie rozwiązywanie spraw życiowych w celu przywrócenia im zdolności do samodzielnego rozwiązywania problemów, a także prowadzenie przez pracowników socjalnych poradnictwa dla osób będących w trudnej sytuacji życiowej. Istotne jest nawiązywanie współpracy międzyinstytucjonalnej oraz wspieranie w uzyskiwaniu pomocy ze strony właściwych organów, instytucji i organizacji oraz pobudzanie społecznej aktywności i inspirowanie działań samopomocowych. Zadaniem osób zatrudnionych w sferze pomocy społecznej jest inicjowanie nowych form udzielania pomocy oraz współuczestniczenie $\mathrm{w}$ inspirowaniu, opracowaniu, wdrożeniu oraz rozwijaniu programów społecznych. Jednym z obowiązków zawodowych pracowników socjalnych jest ujawnianie, analizowanie i interpretowanie potrzeb oraz problemów społecznych mających wpływ na kształtowanie właściwych stosunków międzyludzkich, podnoszenie jakości życia oraz rozwiązywanie kwestii społecznych oraz doskonalenie i poszukiwanie nowych rozwiązań w dziedzinie pracy socjalnej. Ponadto pracownicy socjalni zobowiązani są do uczestnictwa w różnego rodzaju formach doskonalenia i dokształcania, podnoszących poziom kwalifikacji zawodowych, czy też inicjowania i udziału w badaniach problemów społecznych (diagnoza problemów), monitorowania oraz ewaluacji programów i działań - Ustawa z dnia 12 marca 2004 roku o pomocy społecznej (Dz.U. 2004 Nr 64 poz. 593: 84-85). 
Ewa Kantowicz podkreśla znaczenie posiadania wysokiego poziomu kompetencji zawodowych. Wśród nich wyróżnia:

- kompetencje interpretacyjne - zdolność do rozumienia rzeczywistości społecznej, dokonania refleksji nad sobą i własną pracą (warsztat metodyczny) oraz autorefleksji nad własnymi relacjami z drugim człowiekiem, społecznością, grupą;

- kompetencje autokreacyjne - czyli struktura poznawcza, na którą składają się przekonania, system wartości, zdolności, wiedza i sposób doświadczania świata. Dzięki nim człowiek podejmuje działania oparte na suwerennych decyzjach podejmowanych na podstawie wiedzy i zinterioryzowanego systemu norm i wartości;

- kompetencje realizacyjne, które odnoszą się do wiedzy o charakterze technicznym pozwalającej na posługiwanie się metodami, technikami i środkami działania w zakresie pracy społecznej (Kantowicz 2001: 105-107).

Oprócz wiedzy w przypadku pracownika socjalnego ważne jest posiadanie kompetencji społecznych, które warunkują skuteczność oddziaływań pomocowych. Model kompetencji społecznych Stanleya Greenspana ujmuje kompetencje społeczne jako interpersonalne relacje, które jednostka podejmuje w celu zdobycia społecznych obiektów i opanowania społecznego środowiska (Greenspan 1981: 1-39). Proponuje trzy sposoby jej interpretacji:

- jako zdolność do osiągania celów społecznych, rozumiana jako zainteresowanie celami, które jednostka może osiągnąć, a nie określone zachowania społeczne, które do niego prowadzą;

- jako zespół cech indywidualnych (temperament, charakter, świadomość społeczna), które mogą być uszeregowane według ważności osiągania celów społecznych;

- jako sprawność, czyli wyćwiczenie nabytych reakcji w określonych sytuacjach społecznych.

Michael Argyle zaproponował model kompetencji społecznych, w którym wskazał cechy osoby kompetentnej społecznie. Są nimi: asertywność, gratyfikacja, komunikacja niewerbalna, komunikacja werbalna, empatia, poznawanie i rozwiązywanie problemów, przedstawianie się (autoprezentacja), zdolności w różnych sytuacjach i związkach (Argyle 1998: 88).

Z uwagi na specyfikę pracy z różnymi kategoriami klientów oraz problemów pracownik socjalny jest narażony na ogromną liczbę stresorów płynących nie tylko ze strony klientów, lecz także instytucji, w której jest zatrudniony. O ile sam pracownik socjalny nie jest w stanie przy aktywności zawodowej zminimalizować bodźców stresowych, o tyle może w konstruktywny sposób radzić sobie ze stresem. Mówiąc o stylu radzenia sobie, podkreśla się rolę czynników podmiotowych. Według Normana S. Endlera i Jamesa D.A. Parkera styl radzenia sobie ze stresem to typowy, powtarzalny, uwarunkowany osobowościowo sposób zachowania się jednostki w sytuacji obcowania ze stresorem. W ostatnich latach podkreśla się, że nie tyle doświadczanie sytuacji trudnej, ile skuteczne radzenie sobie z nią może wpływać na dobrostan jednostki. Helena Sęk (2000: 102) wyróżnia zasoby wewnętrzne i zewnętrzne oraz zasoby społeczno-kulturowe. 
Richard S. Lazarus i Sussan Folkman wśród zasobów jednostki wymieniają zdrowie i energię wzmacniające wysiłki jednostki podjęte w celu uporania się ze stresem, pozytywne przekonania o możliwości kontroli i skuteczności podejmowanych działań, zdolność do rozwiązywania problemów (umiejętne poszukiwanie informacji, analizowanie i wybór właściwych planów działań) oraz zdolności społeczne, czyli zgodny z obowiązującymi normami i skuteczny sposób zachowania się wobec innych ludzi. W procesie radzenia sobie ze stresem zasobami istotnymi są głównie indywidualne, relatywnie stałe właściwości jednostki określane jako przekonania i oczekiwania (poczucie koherencji, poczucie własnej wartości, skuteczności, poczucie panowania nad zdarzeniami, dyspozycyjny optymizm), a także asertywność, poczucie humoru i posiadanie pasjonujących zainteresowań. W sytuacjach zawodowych istotną rolę odgrywają takie zasoby, jak kompetencje społeczne i inteligencja emocjonalna oraz wsparcie społeczne (Ogińska-Bulik 2002: 7-15).

\section{Projekt badań własnych}

Na podstawie rozważań teoretycznych oraz wyników dotychczasowych badań (Stanek 2016) w niniejszym artykule zakłada się istnienie związku między poziomem kompetencji a odczuwalnym stresem zawodowym pracowników socjalnych. Prezentowane wyniki są jedynie wycinkiem szerszych badań pod tytułem „Kompetencje pracowników socjalnych w procesie kształcenia” zrealizowanych na próbie liczącej 210 osób, wśród których znaczącą większość stanowiły kobiety $(n=201 ; 95,7 \%)$, pracownicy socjalni oraz osoby przygotowujące się do tego zawodu (studenci) na jednym z uniwersytetów kształcących w zawodzie pracownik socjalny na poziomie studiów pierwszego i drugiego stopnia. Celem głównym przeprowadzonych badań było zgromadzenie danych pozwalających określić poziom kompetencji pracowników socjalnych w toku kształcenia akademickiego. Omawiane kwestie osadzono w nurcie pozytywistycznym strategii ilościowej. Obliczenia statystyczne wykonano za pomocą programu komputerowego SPSS. Do określenia różnic między średnimi wykorzystano jednoczynnikową analizę wariancji, a za miarę siły związku między zmiennymi przyjęto wartości współczynników korelacji Pearsona.

Do zebrania materiału empirycznego posłużono się następującymi metodami badawczymi: analizą dokumentów, sondażem diagnostycznym oraz testem. W badaniach zastosowano także opis statystyczny. Badania zostały przeprowadzone przy użyciu następujących narzędzi: Kwestionariusz Kompetencji Społecznych A. Matczak (KKS-A), Profil Kompetencji Społecznych A. Matczak, K. Martowskiej (PROKOS), Wielowymiarowy Kwestionariusz Samooceny O'Briena i Epsteina (MSEI), Kwestionariusz Poczucia Stresu M. Plopa, R. Makarowskiego (KPS), Kwestionariusz Stylów Radzenia Sobie ze Stresem W. Steuden, S. Okła (CISS), kwestionariusz kompetencji - narzędzie stworzone na potrzeby niniejszych badań. Zmiennymi w badaniu określono: 
1. Radzenie sobie ze stresem, czyli ciąg procesów, które akcentują trzy elementy: (a) związane z obserwacjami i oceną, co dana osoba aktualnie myśli lub robi w sytuacji stresu w przeciwieństwie do tego, co czyni w takiej sytuacji zwykle (odporność na stres jako cecha); (b) związane z tym, co dana osoba aktualnie myśli lub robi w sytuacji stresu w określonym specyficznym kontekście (na przykład choroba, zagrożenie życia); (c) związane ze zmianami zamiarów lub aktów umysłowych w związku z napotykanymi zdarzeniami stresowymi (Terelak 2008: 302).

2. Style radzenia sobie ze stresem uznane za typowe dla danej jednostki sposoby radzenia sobie w trudnych, stresujących sytuacjach. Można wyróżnić trzy rodzaje: (a) styl skoncentrowany na zadaniu - osoba charakteryzująca się takim stylem zazwyczaj w obliczu stresu podejmuje wysiłek, aby rozwiązać problem przez kształcenie poznawcze lub zmianę sytuacji trudnej; (b) styl skoncentrowany na emocjach, polegający na koncentrowaniu się na sobie i własnych reakcjach emocjonalnych związanych ze stresem; (c) styl skoncentrowany na unikaniu, kiedy jednostka nie myśli o problemie, nie koncentruje na nim swej uwagi. Ostatni styl radzenia sobie może przybierać dwie formy: angażowanie się w czynności zastępcze (d) oraz poszukiwanie kontaktów towarzyskich (e).

3. Strukturę doznań stresowych: (a) napięcie emocjonalne; (b) stres zewnętrzny; (c) stres intrapsychiczny.

4. Kompetencje społeczne, traktowane jako złożone umiejętności warunkujące efektywność radzenia sobie w określonego typu sytuacjach społecznych, nabywane w toku treningu społecznego (Matczak, Martowska 2013: 13).

5. Umiejętność, czyli sprawność w wykorzystywaniu odpowiedniej wiedzy przy wykonywaniu określonych zadań, sprawdzona możliwość osiągniecia celu przy zastosowaniu sposobów działania skutecznych w danej sytuacji (Nocuń, Szmagalski 1998: 15). Podstawą założenia był własny model kompetencji „jako zestaw wiedzy, umiejętności i doświadczenia, który decyduje o funkcjonowaniu jednostki w środowisku pracy oraz środowisku społecznym". W toku kształcenia ${ }^{1}$ (w przypadku uzyskiwania

${ }^{1}$ Uprawnienia do wykonywania w Polsce zawodu regulowanego pracownika socjalnego regulują przepisy Ustawy z dnia 12 marca 2004 roku (tekst jedn. Dz.U. z 2018 roku poz. 1508 z późn. zm.) oraz Ustawy z dnia 16 lutego 2007 roku o zmianie ustawy o pomocy społecznej (Dz.U. Nr 48 poz. 320). Zgodnie z art. 116 ust. 1 wyżej wymienionej ustawy o pomocy społecznej kwalifikacje pracownika socjalnego można obecnie uzyskać przez ukończenie trzyletniego kolegium pracowników służb społecznych, o którym mowa w przepisie art. 116 ust. 1 pkt 1 ustawy lub studiów wyższych o kierunku praca socjalna, o których mowa w przepisie art. 116 ust. 1 pkt 2 ustawy. Na podstawie wskazanych powyżej przepisów ustawy o pomocy społecznej do wykonywania zawodu pracownika socjalnego dopuszcza się osoby, które ukończyły odpowiednie studia wyższe pierwszego stopnia (studia licencjackie) lub studia wyższe drugiego stopnia (dwuletnie uzupełniające studia magisterskie) i po ukończeniu tych studiów otrzymały tytuł licencjata lub magistra. Analiza dotyczy kryterium ministerialnego w odniesieniu do wymaganych umiejętności, wykazu przedmiotów, minimalnego wymiaru zajęć dydaktycznych oraz zakresu i wymiaru praktyk zawodowych dla zawodu pracownika socjalnego, realizowanej w szkołach wyższych na kierunkach wymienionych w ust. 1, kierując się koniecznością odpowiedniego przygotowania absolwentów do wykonywania zawodu pracownika socjalnego [ust. 1a 
kwalifikacji na studiach wyższych na kierunku praca socjalna) student zdobywa wiedzę z zakresu aksjologii pracy socjalnej, teorii organizacji i zarządzania w pomocy społecznej, polityki społecznej, prawa, socjologii, psychologii, metodyki pracy socjalnej, etyki pracy socjalnej, stresu i wypalenia zawodowego, organizacji społeczności lokalnych, poszczególnych kategorii klientów i oddziaływań w stosunku do nich. Ponadto w toku edukacji, treningu społecznego, a następnie pracy zawodowej kształtuje się umiejętności wymagane w zawodzie pracownika socjalnego, między innymi umiejętności poznawcze, podejmowania decyzji, interwencji administracyjnych, metodologicznych, operacjonalizacji wiedzy, informacyjne, menedżerskie. Student nabiera również doświadczenia przez wykonywanie zadań zawodowych, realizowanych projektów socjalnych oraz pracy w wolontariacie lub uczestnictwo w szkoleniach, kursach, seminariach czy innych formach kształcenia. Zestawienie wiedzy, umiejętności i doświadczenia w toku przygotowania do zawodu pracownika socjalnego zostaje potwierdzone kwalifikacjami w postaci dyplomu ukończenia studiów, a gdy doda się predyspozycje i cechy osobowości, wszystko razem powinno być gwarantem profesjonalizmu, rzetelnego i prawidłowego wykonywania przyszłych zadań zawodowych z uwzględnieniem wszystkich zasad etyki pracy pracownika socjalnego.

\section{Wyniki badań}

Podjęta problematyka kompetencji w aspekcie doświadczalnego stresu i radzenia sobie ze stresem wydaje się zasadna, gdyż posiadane kompetencje, w tym przede wszystkim kompetencje społeczne, są wyznacznikiem efektywności funkcjonowania człowieka. Należą one, obok inteligencji emocjonalnej i kreatywności, do cech najbardziej pożądanych przez pracodawców. Szczególne znaczenie mają kompetencje w zawodzie pracownika socjalnego, od którego wymaga się nie tylko szerokiego zakresu wiedzy pedagogicznej, psychologicznej, socjologicznej czy prawnej, lecz także umiejętności warunkujących „sprawność zarządzania sobą" w sytuacjach społecznych i wysoką skuteczność interpersonalną (Smółka 2008: 15).

\section{Posiadane kompetencje a stres}

Sprawdzono, czy istnieje związek między poziomem kompetencji a stresem. W tym celu wykonano analizę korelacji $r$-Pearsona. Zaobserwowano słaby ujemny związek między poziomem posiadanych kompetencji a stresem.

Rozporządzenia Ministra Pracy i Polityki Społecznej z dnia 25 stycznia 2008 roku w sprawie specjalności przygotowującej do zawodu pracownika socjalnego realizowanej w szkołach wyższych (Dz.U. z 2008 roku Nr 27 poz. 158)]. 
Tabela 1. Matryca korelacji między poziomem kompetencji a stresem

\begin{tabular}{|c|c|c|c|c|}
\hline & KPS_NE & KPS_SZ & KPS_SI & KPS \\
\hline PROKOS_KA & $-0,175^{\star}$ & $-0,173^{*}$ & $-0,283^{\star *}$ & $-0,242^{\star *}$ \\
\hline PROKOS_KK & $-0,163^{*}$ & $-0,138^{\star}$ & $-0,229^{\star *}$ & $-0,193^{\star *}$ \\
\hline PROKOS_KT & $-0,181^{\star *}$ & $-0,183^{\star *}$ & $-0,262^{\star *}$ & $-0,241^{\star *}$ \\
\hline PROKOS_ZS & n.i. & n.i. & $-0,225^{\star *}$ & $-0,166^{*}$ \\
\hline PROKOS_KS & $-0,155^{*}$ & $-0,150^{*}$ & $-0,200^{* *}$ & $-0,186^{* *}$ \\
\hline KKS_I & n.i. & n.i. & $-0,190^{\star *}$ & $-0,146^{*}$ \\
\hline KKS_ES & $-0,171^{\star}$ & $-0,152^{\star}$ & $-0,230^{\star \star}$ & $-0,230^{\star *}$ \\
\hline KKS_A & $-0,148^{\star}$ & $-0,168^{\star}$ & $-0,253^{\star *}$ & $-0,225^{\star *}$ \\
\hline KKS & $-0,174^{*}$ & $-0,170^{*}$ & $-0,265^{\star *}$ & $-0,241^{\star *}$ \\
\hline Wiedza_NW & $-0,190^{\star *}$ & $-0,165^{\star}$ & $-0,145^{\star}$ & n.i. \\
\hline Umiejętności_NW & $-0,322^{\star *}$ & $-0,262^{\star *}$ & $-0,315^{\star *}$ & n.i. \\
\hline Doświadczenie_NW & n.i. & n.i. & n.i. & n.i. \\
\hline
\end{tabular}

PROKOS - Profil Kompetencji Społecznych oraz podskale: kompetencje asertywne (skala A), kompetencje kooperacyjne (skala K), kompetencje towarzyskie (T), zaradność społeczna (skala Z) i kompetencje społecznikowskie (skala S).

Źródło: Opracowanie własne.

Wyniki badań wskazują, że im wyższy poziom kompetencji, tym niższy stres. Można przypuszczać, że pracownicy socjalni, którzy reprezentują wysoki poziom kompetencji, mimo stresujących bodźców płynących ze środowiska zewnętrznego w mniejszym stopniu odczuwają stres. Należy pamiętać, że między innymi kompetencje interpersonalne umożliwiają jednostce bardziej optymistycznie funkcjonować w sytuacjach zagrożenia, szczególnie tych długofalowych. Cechy osobowości, to jest: otwartość, empatyczność, optymizm, zdolność rozumienia innych, pozytywny stosunek do innych, umożliwiają ekspresję gromadzonych emocji, nie dopuszczając do ich kumulowania się, ale również korzystanie ze wsparcia społecznego oferowanego w różnej formie przez otoczenie.

Badacze stresu zorientowani bardziej rozwojowo wiążą nabywanie kompetencji do radzenia sobie ze stresem (bogate zasoby) z wczesnymi doświadczeniami socjalizacyjnymi.

\section{Posiadane kompetencje a style radzenia sobie ze stresem}

W badaniu sprawdzono, czy kompetencje wiążą się ze stylami radzenia sobie ze stresem w przypadku pracowników socjalnych. W tym celu wykonano analizę korelacji $r$-Pearsona. Z badań wynika, że styl skoncentrowany na zadaniu (CISS1_ZACH_ZAD) wiąże się słabo negatywnie ze wszystkimi rodzajami kompetencji KKS, co oznacza, że im wyższy poziom kompetencji, tym rzadziej używany jest ten styl radzenia sobie ze stresem, natomiast istnieje słaby dodatni związek między kompetencjami a stylem skoncentrowanym na emocjach (CISS2_ZACH_EMO). Oznacza to, że pracownicy socjalni, których można określić jako kompetentnych, radzą sobie ze stresem emocjami, a nie zadaniami. 
Nie ma związku kompetencji z angażowaniem się w czynności zastępcze, natomiast słaby związek ujemny zaobserwowano między zachowaniami unikowymi i poszukiwaniem towarzystwa a KKS_I oraz KKS_A oraz między poszukiwaniem towarzystwa a ogólnym wynikiem KKS. Oznacza to, że im wyższy poziom tych kompetencji, tym rzadziej stosowany jest dany styl radzenia sobie ze stresem.

Wyniki te nie pokrywają się z wynikami badań prowadzonych przez autorkę w kontekście wypalenia zawodowego pracowników socjalnych (Stanek 2016: 179-181), z których wynika, że osoby wypalone zawodowo częściej niż pracownicy socjalni niewypaleni w celu poradzenia sobie ze stresem wykorzystują zachowania emocjonalne, natomiast rzadziej zachowania zadaniowe.

Aktualne badania wskazują, że nie ma związku kompetencji z zachowaniami unikowymi oraz angażowaniem się w czynności zastępcze, natomiast słaby związek ujemny zaobserwowano między PROKOS_KK, KT I ZS a poszukiwaniem towarzystwa, co oznacza, że im wyższy poziom tych kompetencji, tym rzadziej występuje poszukiwanie towarzystwa (por. tabela 2).

Tabela 2. Matryca korelacji między poziomem kompetencji a stylami radzenia sobie ze stresem

\begin{tabular}{|c|c|c|c|c|c|}
\hline & $\begin{array}{c}\text { CISS1_- } \\
\text { ZACH_ZAD }\end{array}$ & $\begin{array}{c}\text { CISS2_- } \\
\text { ZACH_EMO }\end{array}$ & $\begin{array}{c}\text { CISS3_ZACH_ } \\
\text { UNIK }\end{array}$ & $\begin{array}{c}\text { CISS3A_CZ_C } \\
\text { ZAST }\end{array}$ & $\begin{array}{c}\text { CISS3B } \\
\text { POSZ_- } \\
\text { TOW }\end{array}$ \\
\hline PROKOS_KA & $-0,314^{* *}$ & $-0,379^{* *}$ & $-0,211^{\star *}$ & $-0,267^{\star *}$ & $-0,190^{* *}$ \\
\hline PROKOS_KK & $0,219^{\star *}$ & $0,171^{*}$ & $0,191^{\star *}$ & $0,182^{\star *}$ & $0,149^{*}$ \\
\hline PROKOS_KT & n.i. & n.i. & n.i. & n.i. & n.i. \\
\hline PROKOS_ZS & n.i. & n.i. & n.i. & n.i. & n.i. \\
\hline PROKOS_KS & n.i. & $-0,238^{* *}$ & $-0,176^{*}$ & $-0,205^{\star *}$ & n.i. \\
\hline KKS_I & $-0,268^{\star *}$ & n.i. & $-0,160^{*}$ & n.i. & $-0,282^{* *}$ \\
\hline KKS_ES & $-0,226^{* *}$ & $0,154^{*}$ & n.i. & n.i. & n.i. \\
\hline KKS_A & $-0,253^{\star *}$ & $0,135^{\star}$ & $-0,140^{\star}$ & n.i. & $-0,218^{\star *}$ \\
\hline KKS & $-0,287^{\star *}$ & $0,158^{*}$ & n.i. & n.i. & $-0,217^{\star *}$ \\
\hline Wiedza_NW & $-0,225^{\star *}$ & $0,181^{* *}$ & n.i. & n.i. & n.i. \\
\hline Umiejętności_NW & $-0,443^{\star *}$ & $0,306^{* *}$ & n.i. & n.i. & n.i. \\
\hline Doświadczenie_NW & $-0,177^{\star}$ & n.i. & n.i. & n.i. & n.i. \\
\hline \multicolumn{6}{|l|}{${ }^{\star} p<0,05 ;{ }^{* *} p<0,01$} \\
\hline $\begin{array}{l}\text { CISS1_ZACH_ZAD } \\
\text { CISS2_ZACH_EMO } \\
\text { CISS3_ZACH_UNIK } \\
\text { CISS3A_CZ_ZAST - } \\
\text { CISS3B_POSZ_TOW }\end{array}$ & $\begin{array}{l}\text { - zachowanie zad } \\
\text { - zachowanie em } \\
\text { - zachowanie unik } \\
\text { zynności zastępcz } \\
\text { - poszukiwanie to }\end{array}$ & $\begin{array}{l}\text { iowe } \\
\text { jonalne } \\
\text { ve }\end{array}$ & & & \\
\hline
\end{tabular}

Źródło: Opracowanie własne. 


\begin{tabular}{|c|c|c|}
\hline 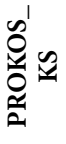 & 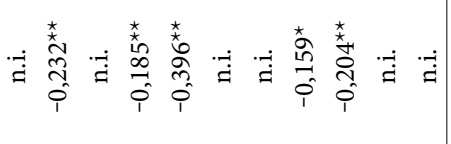 & \\
\hline$\overbrace{\substack{1 \\
0}}^{n}$ & 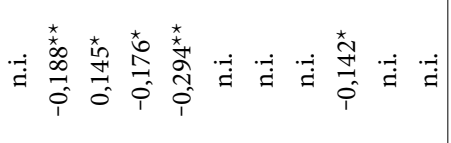 & \\
\hline 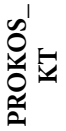 & 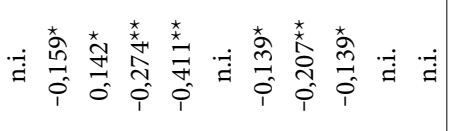 & \\
\hline 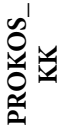 & 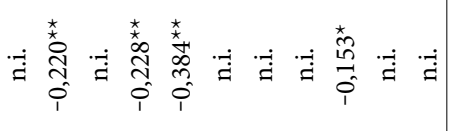 & \\
\hline 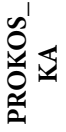 & 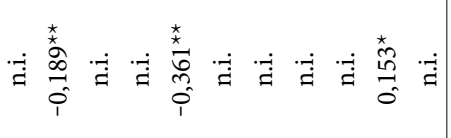 & \\
\hline$\tilde{z}$ & 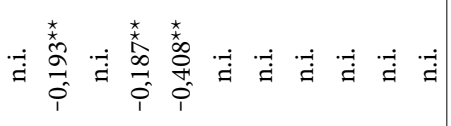 & \\
\hline $\begin{array}{l}4 \\
y \\
y\end{array}$ & 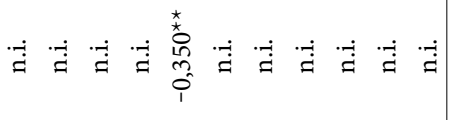 & \\
\hline 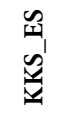 & 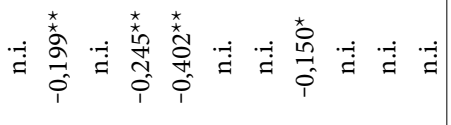 & \\
\hline$\vec{y}$ & 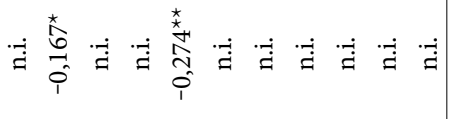 & \\
\hline & 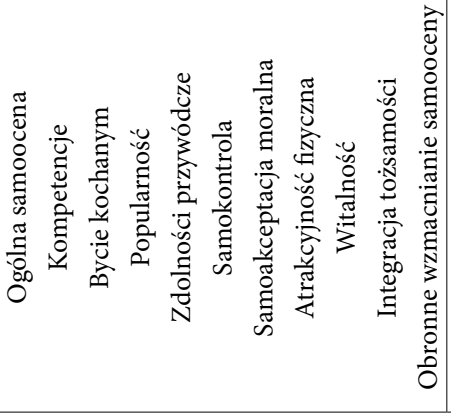 & 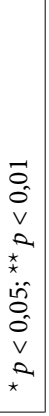 \\
\hline
\end{tabular}




\section{Posiadane kompetencje a samoocena}

Jednym z czynników różnicujących kompetencje społeczne jest samoocena, która polega na świadomym ustosunkowaniu się i wartościowaniu zarówno swoich fizycznych, jak i psychicznych cech oraz możliwości (Kanios 2010: 45). Sprawdzono, czy istnieje związek między kompetencjami a samooceną. W tym celu wykonano analizę korelacji $r$-Pearsona. Okazało się, że między ogólną samooceną a kompetencjami KKS nie ma związku.

\section{Samoocena a odczuwany stres}

W celu dokonania kolejnych analiz sprawdzono, czy samoocena wiąże się z odczuwanym stresem. W tym celu wykonano analizę korelacji $r$-Pearsona. Okazało się, że ogólna samoocena wiąże się jedynie słabo negatywnie $\mathrm{z}$ napięciem emocjonalnym, co oznacza, że im lepsza samoocena, tym mniejsze napięcie. Między niektórymi podskalami występuje słaba korelacja ujemna, co oznacza, że wraz ze wzrostem na przykład poczucia bycia kochanym maleje napięcie emocjonalne.

Tabela 4. Matryca korelacji między samooceną a odczuwanym stresem

\begin{tabular}{|c|c|c|c|c|}
\hline & KPS_NE & KPS_SZ & KPS_SI & KPS \\
\hline Ogólna samoocena & $-0,137^{\star}$ & n.i. & n.i. & n.i. \\
\hline Kompetencje & n.i. & n.i. & n.i. & n.i. \\
\hline Bycie kochanym & $-0,352^{* *}$ & $-0,358^{\star *}$ & $-0,305^{\star *}$ & $-0,344^{* *}$ \\
\hline Popularność & n.i. & n.i. & n.i. & n.i. \\
\hline Zdolności przywódcze & n.i. & $0,193^{\star *}$ & $0,242^{\star *}$ & $0,208^{* *}$ \\
\hline Samokontrola & $-0,228^{* *}$ & $-0,244^{\star *}$ & n.i. & $-0,192^{* *}$ \\
\hline Samoakceptacja moralna & $-0,194^{* *}$ & $-0,209^{* *}$ & $-0,137^{\star}$ & $-0,169^{\star}$ \\
\hline Atrakcyjność fizyczna & n.i. & n.i. & n.i. & n.i. \\
\hline Witalność & n.i. & n.i. & n.i. & n.i. \\
\hline Integracja tożsamości & $-0,322^{* *}$ & $-0,236^{\star *}$ & $-0,263^{\star *}$ & $-0,282^{\star *}$ \\
\hline Obronne wzmacnianie samooceny & $-0,331^{\star *}$ & $-0,307^{* *}$ & $-0,241^{\star *}$ & $-0,281^{* *}$ \\
\hline
\end{tabular}

Źródło: Opracowanie własne.

\section{Samoocena a style radzenia sobie ze stresem}

Czy samoocena wiąże się ze stylami radzenia sobie ze stresem? W tym celu wykonano analizę korelacji $r$-Pearsona. Zaobserwowano słabe korelacje dodatnie, co oznacza, że im wyższa samoocena, tym lepsze radzenie sobie ze stresem. 
Tabela 5. Matryca korelacji między samooceną a stylami radzenia sobie ze stresem

\begin{tabular}{|c|c|c|c|c|c|}
\hline & $\begin{array}{c}\text { CISS1_ZACH_ } \\
\text { ZAD }\end{array}$ & $\begin{array}{c}\mathrm{CISS2}_{-} \\
\mathrm{ZACH}_{-} \\
\mathrm{EMO}\end{array}$ & $\begin{array}{c}\mathrm{CISS3}_{-} \\
\mathrm{ZACH}_{-} \\
\text {UNIK }\end{array}$ & $\begin{array}{c}\text { CISS3A_ }_{-} \\
\text {CZ_- }_{-} \\
\text {ZAST }\end{array}$ & $\begin{array}{l}\text { CISS3B_- } \\
\text { POSZ_TOW }\end{array}$ \\
\hline Ogólna samoocena & $0,298^{* *}$ & $0,143^{*}$ & n.i. & n.i. & $0,161^{*}$ \\
\hline Kompetencje & $0,238^{\star *}$ & n.i. & n.i. & n.i. & n.i. \\
\hline Bycie kochanym & $0,212^{* *}$ & $0,345^{\star *}$ & n.i. & n.i. & n.i. \\
\hline Popularność & $0,152^{*}$ & n.i. & $0,246^{* *}$ & $0,162^{*}$ & $0,222^{\star *}$ \\
\hline Zdolności przywódcze & $0,292^{\star *}$ & $-0,155^{\star}$ & n.i. & n.i. & n.i. \\
\hline Samokontrola & $0,282^{* *}$ & $0,243^{\star *}$ & n.i. & n.i. & n.i. \\
\hline Samoakceptacja moralna & $0,190^{* *}$ & $0,220^{\star *}$ & n.i. & n.i. & n.i. \\
\hline Atrakcyjność fizyczna & n.i. & n.i. & $0,174^{*}$ & n.i. & n.i. \\
\hline Witalność & $0,146^{*}$ & n.i. & n.i. & n.i. & n.i. \\
\hline Integracja tożsamości & $0,173^{*}$ & $0,294^{\star *}$ & n.i. & n.i. & n.i. \\
\hline Obronne wzmacnianie samooceny & n.i. & $0,384^{* *}$ & $0,299^{* *}$ & $0,264^{\star *}$ & $0,192^{* *}$ \\
\hline${ }^{*} p<0,05 ;{ }^{* *} p<0,01 ;{ }^{* * *} p<0,001$ & & & & & \\
\hline
\end{tabular}

Źródło: Opracowanie własne.

\section{Podsumowanie i wnioski}

Na podstawie przeprowadzonych badań można stwierdzić, że pracownicy socjalni, pomimo uczestniczenia w procesie edukacji permanentnej, słabo oceniają swoje kompetencje. Powszechnie narażeni są na bodźce stresowe, ale reprezentują różne sposoby radzenia sobie ze stresem.

Pracownicy socjalni, którzy wykazują wysoki poziom kompetencji, lepiej radzą sobie ze stresem i w mniejszym natężeniu ich organizm reaguje na stresory.

Badania nie pokazują, który ze stylów radzenia sobie ze stresem wybierają pracownicy socjalni, a jedynie korelacje między nimi. Wyniki przeprowadzonych badań wskazują natomiast, że im wyższy poziom kompetencji, tym rzadziej jednostka używa zadaniowego stylu radzenia sobie ze stresem. Kompetentni pracownicy socjalni radzą sobie ze stresem emocjami, a nie zadaniami.

Czy odpowiednie kompetencje stanowią zasób jednostki w przeciwdziałaniu stresowi? Czy wykształcone umiejętności w toku kształcenia pomagają pracownikowi socjalnemu radzić sobie ze stresem? Zaprezentowane wyniki badań nie dają jasnych odpowiedzi na zadane przez autorkę pytania, ale mogą stanowić podstawę kolejnych badań odnoszących się do kompetencji i stresu pracowników socjalnych.

\section{Bibliografia}

Argyle M. (1998). Zdolności społeczne, w: S. Moscovici (red.), Psychologia społeczna w relacji ja-inni, tłum. M. Cielecki. WSiP, Warszawa. 
Beckett Ch. (2010). Podstawy dla praktyków pracy socjalnej, tłum. M. Jasiński, B. Maliszewska. Wydawnictwo APS, Warszawa.

Greenspan S. (1981). Defining childhood social competence: A proposed working model, w: B.K. Keogh (red.), Advances in Special Education, t. 3. JAI Press, Greenwich.

Kanios A. (2010). Społeczne kompetencje studentów do pracy w wolontariacie. Wydawnictwo Uniwersytetu Marii Curie-Skłodowskiej, Lublin.

Kantowicz E. (2001). Pedagogika społeczna wobec kwestii jakości życia. „Pedagogika Społeczna”, 1: 105-117.

Kaźmierczak T. (1994). Charakterystyka zawodu pracownika socjalnego dla potrzeb opracowania programu szkół (wydziałów) pracowników socjalnych. „Praca Socjalna”, 2: 54-55.

Matczak A., Martowska K. (2013). Profil Kompetencji Społecznych. Pracownia Testów Psychologicznych, Warszawa.

Nocuń A.W., Szmagalski J. (1998). Podstawowe umiejętności w pracy socjalnej i ich kształcenie. Wydawnictwo Naukowe „Śląsk”, Katowice.

Ogińska-Bulik N. (2002). Radzenie sobie ze stresem u funkcjonariuszy policji. „Zeszyty Naukowe WSHE w Łodzi”, 1.

Sęk H. (red.) (2000). Wypalenie zawodowe. Przyczyny. Mechanizmy. Zapobieganie. PWN, Warszaw.a

Smółka P. (2008). Kompetencje społeczne. Metody pomiaru i doskonalenia umiejętności interpersonalnych. Oficyna a Wolters Kluwer Business, Kraków.

Stanek K.M. (2016). Wypalenie zawodowe pracowników socjalnych. Stan i uwarunkowania w aspekcie pracy zawodowej. Wydawnictwo Naukowe „Śląsk”, Katowice.

Szczęsna A., Rostkowski T. (red.) (2004). Zarządzanie kompetencjami, w: T. Rostkowski, Nowoczesne metody zarzadzania zasobami ludzkimi. Centrum Doradztwa i Informacji Difin, Warszawa.

Terelak J.F. (2008). Człowiek i stres. Oficyna Wydawnicza Branta, Warszawa-Bydgoszcz. 